\title{
Pengembangan Potensi Perempuan Desa Baturono, Kecamatan Sukodadi, Kabupaten Lamongan Dalam Peningkatan \\ Dan Inovasi Perekonomian Desa
}

\author{
Herlina Suksmawati ${ }^{1}$, Yudiana Indriastuti ${ }^{2}$ \\ ${ }^{1}$ IImu Komunikasi, UPN "Veteran" Jawa Timur \\ ${ }^{2}$ IImu Komunikasi, UPN "Veteran" Jawa Timur \\ email : herlinasuksma@gmail.com
}

\begin{tabular}{l}
\hline Info Artikel \\
\hline Masuk: \\
Revisi: \\
Diterima: \\
Terbit: \\
Keywords: \\
innovation, rural women, \\
singkong, urban \\
P-ISSN: xxxxxxx \\
$\quad$ : xxxxxxx \\
DolssN: \\
Rxxxxxx \\
inovasi, perempuan desa, \\
pedesaan, singkong
\end{tabular}

\begin{abstract}
Competition in Wingko Babat home industry products demands that women's groups in the village of Baturono, Sukodadi, Lamongan Regency develop the taste of Wingko Babat products with different alternative raw materials. Through community service activities consisting of training and mentoring in village programs, Baturono village women use cassava as a basis for Wingko Babat, as an effort to take advantage of the village's trade. On the other hand, they are also struggling to develop creativity to increase the taste with a variety of flavors that will attract consumers, such as durian, pandanus, jackfruit and strawberry as a form of innovation for processed Wingko Babat products. Besides, in the digital era village, women are not only limited to work-oriented to production. Training in the use of online media as a means of promotion and marketing like industrial products in urban areas is expected to be able to develop their businesses and provide income or understand families.
\end{abstract}

\footnotetext{
Abstrak

Persaingan home industry produk Wingko Babat menuntut kelompok perempuan di Desa Baturono, Sukodadi, Kabupaten Lamongan mengembangkan cita rasa produk Wingko Babat dengan alternatif bahan dasar berbeda. Melalui kegiatan pengabdian masyarakat berupa pelatihan dan pendampingan dalam upaya inovasi perekonomian desa, perempuan desa Baturono menggunakan singkong sebagai bahan dasar Wingko Babat, sebagai upaya memanfaatkan komoditas desa tersebut. Disisi lain, mereka juga berani berupaya mengembangkan kreatifitas peningkatan rasa dengan variasi rasa yang dianggap akan dapat menarik konsumen segala usia, seperti halnya rasa durian, pandan, nangka dan strawberry sebagai bentuk inovasi terhadap olahan produk Wingko Babat. Selain itu, di era digital perempuan desa tidak hanya terbatas melakukan pekerjaan yang berorientasi pada produksi semata. Pelatihan pemanfaatan media online sebagai sarana promosi dan pemasaran layaknya industri produk makanan di perkotaan, diharapkan mampu mengembangkan usaha mereka dan memberikan pemasukan atau penghasilan keluarga.
} 


\section{PENDAHULUAN}

Usaha home industri berbasis potensi lokal yaitu produk inovatif olahan singkong yaitu wingko babat berbahan dasar singkong, yang dikembangkan di desa Baturono, Kecamatan Sukodadi, Kabupaten Lamongan. Hal ini perlu dikembangkan, mengingat potensi perempuan di desa ini diantaranya adalah semangat yang tinggi dalam meningkatkan taraf hidupnya, sementar kemampuan sumber daya manusia yang sangat terbatas, sehingga memerlukan sentuhan inovasi dari pihak lain yaitu perguruan tinggi melalui kegiatan pengabdian kepada masyarakat. Salah satu upaya Pemerintah Desa dalam meningkatkan gerak perekonomian desa yaitu dengan memberdayakan perempuan sekitar untuk lebih kreatif mengolah komoditas setempat meningkatkan perkonomian rumah tangga. Selain memberdayakan perempuan sekitar hal ini juga dapat merangkul seluruh potensi dan kearifan lokal desa. Kegiatan ekonomi yang berkembang menurut kekhasan desa bertujuan meningkatkan perekonomian desa.

Dalam rangka meningkatkan kesejahteraan masyarakat khususnya kaum perempuan perlu diadakan pendekatan tersendiri. Pendekatan pemberdayaan ini kendati menyadari pentingnya meningkatkan kekuasaan wanita, namun pendekatan ini lebih berupaya untuk mengidentifikasi kekuasaan bukan sekedar dalam kerangka dominasi yang satu terhadap yang lain, melainkan lebih dalam kerangka kapasitas wanita untuk meningkatkan kemandirian dan kekuatan internal. Pemberdayaan didefinisikan sebagai suatu proses (Gutierrez, 1990), sebagai suatu intervensi (Salomo, 1976), dan sebagai suatu keterampilan. Pemberdayaan juga telah dipandang sebagai suatu strategi khusus untuk memberdayakan wanita menjadi lebih mandiri (Browne, 1995). Pemberdayaan masyarakat merupakan strategi yang dapat dilakukan dalam mengatasi kemiskinan dalam upaya untuk meningkatkan harkat dan martabat lapisan masyarakat, yang dalam kondisi sekarang tidak mampu untuk melepaskan diri dari perangkap kemiskinan dan keterbelakangan (Kartasasmita, 1996, h. 144).

Pengembangan usaha wingko babat berbahan dasar singkong ini merupakan tindak lanjut pemberdayaan perempuan di Desa Baturono. Hal ini dipandang penting bagi masyarakat desa Baturono, khususnya bagi para perempuan dalam upaya meningkatkan pendapatan dan kesejahteraan keluarga, karena akan dievaluasi. Bahwa pembuatan wingko babat berbahan dasar singkong dapat mengalami peningkatan produksi. Berdasarkan observasi di lapangan pada dusun Doro cilik, Kelurahan Baturono, Kecamatan Sukodadi Lamongan, petani singkong enggan memanen singkong, bahkan cenderung membuang hasil panen karena harga singkong yang jatuh akibat berlimpahnya panen. Dusun ini mempunyai sawah yang hanya bisa dipanen padi 2 kali dalam setahun, waktu antar panen dipakai untuk menanam singkong.

Mengkaji perempuan tidak dapat dilepaskan dari nilai atau ketentuan yang membedakan identitas sosial laki-laki dan perempuan, serta apa yang harus dilakukan oleh perempuan dan apa yang harus dilakukan laki-laki dalam ekonomi, politik, sosial dan budaya baik dalam kehidupan keluarga, masyarakat dan bangsa (Budiman, 1985; Megawangi 1997). Pemberdayaan perempuan merupakan proses kesadaran dan pembentukan kapasitas(capacity building) terhadap partisipasi yang lebih besar untuk memiliki kekuasaan dan pengawasan dalam pembuatan keputusan dan transformasi (transformation action) agar perempuan dapat menghasilkan sesuatu yang bermanfaat (Karl, 1995 dalam Man Yee Kan, 2002). Memisahkan rantai kemiskinan dianggap dapat membebaskan dari kemiskinan, menumbuhkan kekuatan dan memiliki kemandirian. Pemberdayaan perempuan sebagai proses terus menerus untuk meningkatkan kemampuan dan kemandirian perempuan dalam upaya meningkatkan kesejahteraan keluarga.

Desa Baturono merupakan salah satu desa di Kecamatan Sukodadi Kabupaten Lamongan. Selama ini Desa Baturono memiliki komoditas ubi kayu atau singkong telah dibudidayakan di Lamongan sejak ratusan tahun silam. Komoditas ini belum berperan strategis bagi pembangunan ekonomi nasional terutama untuk meningkatkan kesejahteraan masyarakat setempat. Padahal, singkong memiliki peluang besar untuk diorbitkan menjadi komoditas unggulan nasional.

Singkong atau sering juga disebut Ubi kayu atau ketela pohong adalah makanan umbi-umbian yang mengandung kalori dan kabohidrat yang tinggi. Singkong atau ubi kayu ini banyak dijadikan makanan pokok dinegara-negara berkembang terutama di negara adikuasa Amerika serikat yang dikenal sebutan Cassava sedangkan bahasa ilmiahnya disebut dengan Manihot esculenta. Selain dapat dijadikan makanan pokok yang kaya dengan karbohidrat dan kalori, singkong juga memiliki beberapa manfaat bagi orang yang mengkonsumsinya.

Faktor rendahnya pendidikan, keterampilan, ketiadaan modal serta rendahnya aksesibilitas menyebabkan kelompok perempuan ini menjadi kelompok yang termarginalkan (Zid, 2011). Tidak 
hanya lak-laki yang memiliki penghasilan yang cukup rendah, namun menurut Suhartini (2009), terdapat suatu kenyataan secara umum bahwa posisi wanita di pedesaan di Indonesia khususnya dan negara sedang berkembang pada umumnya, posisi mereka termarginalisasi. Hal tersebut yang menyebabkan kemiskinan tidak lepas dari kaum wanita.

Pendidikan menjadi penting karena dengan pemberdayaan masyarakat akan meningkatkan kapasitas pribadi maupun kelompok. Fungsi kelompok bagi individu adalah memberikan latihan dan dukungan bagi para anggotanya, membantu perkembangan psikologis individu dengan cara memberikan wadah bagi perkembangan intelektualitas maupun emosinya. Sedangkan fungsi kelompok bagi organisasi ialah menumbuhkan saling belajar melalui saling tukar pengalaman, pendapat, informasi, persepsi dan keyakinan antar anggota kelompok. Oleh karena itu kelompok dimanfaatkan dalam organisasi untuk membantu orang-orang yang terlibat dalam organisasi mengatasi kekhawatiran, ketidakberhasilan, dan keengganan bekerjasama antar anggota. Pendidikan masyarakat merupakan suatu proses dimana upaya pendidikan diwujudkan secara terpadu dengan upaya penduduk setempat untuk meningkatkan kondisi sosial, ekonomi dan budaya yang lebih bermanfaat dan memberdayakan masyarakat. Oleh karena itu diperlukan model pemberdayaan wanita melalui pendidikan life skills berbasis berbasis ekonomi produktif dengan pemanfaatan potensi lokal dalam upaya meningkatkan kesejahteraan masyarakat. (Mulyono, 2007).

\section{RUMUSAN MASALAH}

Dari situasi tersebut diatas dapat diuraikan permasalahan-permasalahan yang sedang dihadapi oleh perempuan di desa Baturono dalam mengembangkan produk inovatif mereka tentang pembuatan wingko babat berbahan dasar singkong. Pertama pengetahuan mereka tentang pembuatan wingko babat berbahan dasar singkong masih kurang, sehingga perlu dilakukan pelatihan pembuatan wingko babat yang terbuat dari singkong yang mempunyai nilai jual tinggi tanpa mengurangi kualitasnya yang sarat dengan gizi, sehingga kelompok ibu-ibu bisa menjual hasil pembuatan makanannya ke konsumen. Permasalahan kedua adalah pemasaran yaitu masalah keterbatasan akses pasar bagi kelompok usaha (pemasaran). Masalah pemasaran merupakan masalah yang prinsip dalam hubungannya dengan peningkatan produksi. Keberhasilan memasarkan produk, dengan sendirinya diharapkan dapat menjamin kehidupan serta menjaga kestabilan kegiatan-kegiatan operasional home industry. Oleh karena itu kita harus mencari jaringan pemasaran yang cocok agar dapat menumbuh- kembangkan produksi kue wingko babat yang terbuat dari singkong yang dapat menjanjikan untuk dikembangkan.

\section{METODE PELAKSANAAN}

Pemasaran adalah proses sosial di mana individu dan kelompok mendapatkan apa yang dibutuhkan dan diinginkan dengan menciptakan, menawarkan dan menukar produk yang bernilai dengan orang lain (Kotler 2005). Pasar dalam manajemen pemasaran adalah orang atau organisasi yang membutuhkan produk yang dipasarkan dan mereka memiliki daya beli yang cukup untuk memenuhi kebutuhan mereka. Strategi pemasaran sebagai alat fundamental yang direncanakan untuk mencapai tujuan perusahaan dengan mengembangkan keunggulan kompetitif yang berkelanjutan melalui pasar yang dimasukkan dan program pemasaran yang digunakan untuk melayani target pasar ini (Tull dan Kahle, 1990). Strategi pemasaran memberikan arahan mengenai variabel seperti segmentasi pasar, identifikasi target pasar, positioning, elemen bauran pemasaran, dan biaya bauran pemasaran. Strategi pemasaran adalah bagian integral dari strategi bisnis yang memberikan arahan untuk semua fungsi manajemen organisasi. Oleh karena itu terkait dengan bagaimana memasarkan hasil industri rumahan Wingko Babat yang dilakukan oleh sekelompok ibu rumah tangga di Desa Baturono, Sukodadi, Lamongan, perlu menggunakan strategi pemasaran sehingga mereka mampu menembus pasar sehingga mereka diharapkan untuk dapat bersaing dengan jenis makanan lain.

Metode yang digunakan dalam kegiatan pengabdian masyarakat ini meliputi : 1) Pelatihan produksi, dilakukan dalam bentuk penyuluhan dan praktik pembuatan Wingko Babat yang terbuat dari singkong dengan konsep adonan rasa dengan kualitas yang baik. Dalam produksi produksi Wingko 
Babat yang terbuat dari singkong. 2) Pelatihan pemasaran dilakukan dengan mengatur praktik konseling dan pemasaran, khususnya pengemasan, promosi, teknik penjualan, baik online maupun offline. 3) Pemantauan dan perkembangan produksi, dan 4) Evaluasi

\section{PEMBAHASAN}

Salah satu kelompok perempuan di desa Baturono adalah masyarakat yang mayoritas bekerja sebagai ibu rumah tangga. Dalam upaya peningkatkan pendapatan keluarga, dalam hal ini mencari tambahan penghasilan keluarga, baik dalam kegiatan bercocok tanam, juga dalam kegiatan sambilan membuat kue. Setelah diberikan pelatihan kelompok perempuan/ ibu rumah tangga mampu mengolah wingko babat berbahan dasar singkong secara mandiri seperti berdasarkan komposisi rasa yang tepat, sehingga dapat menghasilkan konsep citra rasa yang mampu bersaing dengan jenis home industry makanan kue basah yang lain.

Dalam pembuatan wingko babat yang berbahan dasar singkong, bahan baku utama yang digunakan adalah singkong. Pada pembuatan wingko babat untuk mendapatkan hasil yang berkualitas baik, dibutuhkan bahan singkong yang masih segar. Bila bahan baku yang digunakan kurang baik kesegarannya, maka akan mempengaruhi kualitas rasa, dan aroma yang dihasilkan.

Selanjutnya disamping bahan baku, cara membuat wingko babat juga menjadi perhatian yang tidak kalah pentingnya terutama yang menyangkut komposisi bahan atau adonan yang tepat. Oleh karena itu pelatihan yang intensif dan berulang-ulang perlu dilakukan agar produksi wingko babat yang dihasilkan mempunyai citra rasa yang khas dan pada akhirnya mampu bersaing di pasaran dengan jenis-jenis makanan yang lain. Produk Wingko Babat berbahan dasar singkong belum pernah dibuat oleh ibu-ibu maupun masyarakat setempat. Berikut ini adalah resep dalam pembuatan "Wingko bbat berbahan dasar Singkong".

Bahan yang disiapkan adalah:

- 500 gram Singkong

- 2 butir Kelapa parut

- 450 gram Gula

- 2 gram Vanili

- 1/4 sdt Garam

- Mentega secukupnya

- 50 gram Nangka

- Pewarna Kue Coklat dan Kuning, Pandan secukupnya

Cara membuat :

Setelah seluruh bahan-bahan diatas disiapkan, maka selanjutnya adalah cara membuat "Wingko Babat berbahan dasar Singkong", yaitu:

a) Ketela pohong diparut halus, jangan diperas

b) Kelapa diparut memanjang

c) Semua bahan dicampur menjadi satu (ketela parut, kelapa parut, gula, vanili, garam)

d) Uleni bahan tersebut hingga tercampur rata

e) Setalah semua bahan tercampur dengan rata, lalu bagi menjadi dua bagian

f) Satu bagian rasa original dan satu lagi ditambahi bubuk coklat

g) Siapkan loyang anti lengket yang telah diolesi mentega

h) Masukan bahan ke dalam loyang dan panggang dengan api kecil

i) Jangan lupa bahan dibalik supaya kedua permukaan matang dengan rata

j) Panggang kira-kita 15 sampai 20 menit

k) Sajikan

Dari hasil pengamatan di lapangan, ternyata ditemukan beberapa perbedaan dari segi proses pemanggangan. Dalam pelatihan yang telah diberikan, kami membuat dua wingko babat yang dipanggang dengan cara yang berbeda. Yang satu menggunakan oven listrik dan yang satu lagi menggunakan teflon yang langsung diapanaskan diatas kompor. Hasil yang diperoleh ternyata ada perbedaan kematangan, jika menggunakan oven listrik maka permukaan wingko yang matang Cuma dibagian bawah saja, tetapi jika mengunakan teflon tingkat kematangannya jauh lebih merata. Selain dari proses pemanggangan dari sedi rasa juga mempunyai perbedaan, barangkali kalau dari sefi rasa lebih kepada selesa masing-masing yang menikmati wingko babat tersebut. 


\section{Target yang Ingin Dicapai}

Kegiatan Pengabdian Kepada Masyarakat ini adalah untuk mengembangkan produk camilan wingko babat berbahan dasar singkong, khususnya pada peningkatan mutu produksi wingko babat, karena ini merupakan camilan baru bagi warga desa Baturono, Lamongan. Dengan demikian sasaran kegiatan pengabdian kepada masyarakat adalah anggota kelompok ibu-ibu yang berminat untuk menambah penghasilan secara ekonomi akan naik atau berubah dari yang sebelumnya.

\section{Prioritas Persoalan dan Jalan Keluar Pemecahan}

Penentuan prioritas persoalan berdasarkan kesepakatan tim dan mitra adalah : Pengetahuan tentang pengembangan produksi dalam pembuatan wingko babat berbahan dasar singkong dengan komposisi yang tepat/ adonan yang tepat, sehingga dapat menghasilkan cita rasa yang mampu bersaing dengan wingko babat yang berbahan dasar dari ketan. Oleh karena itu diperlukan konsep / resep bagaimana membuat wingko babat berbahan dasar singkong dengan adonan yang tepat.

Manajemen pemasaran. Masalah pemasaran merupakan masalah yang prinsip dalam hubungannya dengan peningkatan produksi, oleh karena itu kita harus mencari manajemen yang sesuai dengan jaringan pemasaran yang cocok agar dapat menumbuhkembangkan produksi wingko babat berbahan dasar singkong yang dapat menjanjikan untuk dikembangkan, termasuk pavkaging dan labeling.

\section{Pendampingan Terpadu}

Telah dipaparkan bahwa dalam pengabdian masyarakat ini, tim dan mitra akan melakukan implementasi channel control strategy. Dalam kaitannya dengan hal tersebut maka pendampingan yang dilakukan oleh tim adalah pendampingan terpadu dan berkelanjutan.

Pendampingan terpadu adalah tim tidak hanya mendampingi mitra dan masyarakat, mitra dalam hal aplikasi teori, namun tim juga akan mendampingi mitra dalam menjelaskan konseptual teoritik. Dalam arti, tim akan mendampingi mitra mulai dari perencanaan sampai pada eksekusi kegiatan pengabdian masyarakat termasuk pelatihan pembuatan web terintegrasi dan cyber marketing, bilamana kondisi memungkinkan.

\section{KESIMPULAN}

Inovasi ini dilakukan sebagai upaya menghadirkan cita rasa alternatif. Selain itu, penggunaan singkong sebagai bahan utama adalah salah satu upaya memaksimalkan produk olahan dari perkebunan desa. Selanjutnya, melalui kegiatan pelatihan pemasaran online, mereka memiliki pengetahuan dasar tentang penggunaan media online untuk memasarkan produk makanan. Dan juga, model pengembangan jaringan pemasaran industri rumah. Hingga saat ini, kegiatan pendampingan terus dilakukan sebagai upaya memantau perkembangan kelompok usaha wanita di Desa Baturono, Sukodadi, Lamongan.

\section{REFERENCES}

Craig Lees, M.,S. Joy and B. Browne, 1995, Consumer Behaviuor, Jhon Willey \& Son, Brisbane. Dwidjowijoto dan Wrihatnolo. 2007. Manajemen Pemberdayaan. Jakarta: PT. Elex

Dwidjowijoto dan Wrihatnolo. 2007. Manajemen Pemberdayaan. Jakarta: PT. Elex

Media Komputindo Kelompok Gramedia.

Gutierrez, L. 1990. "Working with Woman of Color". Social Work.

Hamel, G., and C. K. Prahalad. 1994. Competing For the Future. Boston : Harvard Business Scholl Press.

Insentif Peningkatan Peneliti Dan Perekayasa Kementerian Riset Dan Teknologi (2012).

Kartasasmita, Ginandjar. 1996. Ekonomi Rakyat: Memadukan Pertumbuhan dan Pemerataan ; CIDES, Jakarta. 
Kusnadi 1997 Koperasi Keluarga: Pilihan Kontekstual bagi Masyarakat Nelayan. Jember, Pusat Studi Komunitas Pantai, Universitas Jember

K Suhendra. 2006. Peran Birokrasi Dalam Pemberdayaan Masyarakat. Bandung :

Alfabeta

Megawangi, 1997. Gender Perspektif in Early Childhood Care and Development in Indonesia.resport Submitted to the Consultative Group on Early Childhood Care and Development, MA, USA.

Moser, C.O.N. 1993. Gender planning and developmnet: Theory, practice, and training, Lonon. Roudledge

Muflikhati, Istiqliyah et al. 2010. Kondisi Sossial Ekonomi Dan Tingkat Kesejahteraan Keluarga : Kasus Di Wilayah Pesisir Jawa Barat . Institut Pertanian Bogor. Bogor.

Mulyono, Budi. 2007. Dimensi Sosial Kehidupan Nelayan. PT. Rajawali Press - Jakarta.

Mardikanto, Totok dan Poerwoko Soebianto. 2013. Pemberdayaan Masyarakat

Dalam Perspektif Kebijakan Publik. Bandung : Alfabeta

Moleong, Lexy J. 2017. Metodologi Penelitian Kualitatif. Bandung : PT Remaja

Rosdakarya.

Salomon, Jean Jacques, Francisco R. Sagasti, dan Céline Sachs Jeantet (ed.). The Uncertain Quest: Science, Technology, and Development. Tokyo: United Nations University Press. 1997 